\title{
KESAN EJEN PEDAGOGI DAN RANGSANGAN MULTIMEDIA DALAM KOSWER NUTRI-SCORE TERHADAP KEMAHIRAN BERFIKIR ARAS TINGGI
}

\author{
${ }^{1}$ Norsaliza Sabu, ${ }^{2}$ Noraini Mohamed Noh, ${ }^{3} \mathrm{Che}$ Nidzam Che Ahmad, ${ }^{4}$ Norazilawati Abdullah \\ 1,2,4Fakulti Pembangunan Manusia, Universiti Pendidikan Sultan Idris, Tanjung Malim 35900, Perak \\ ${ }^{3}$ Fakulti Sains dan Matematik, Universiti Pendidikan Sultan Idris, Tanjung Malim 35900, Perak \\ *emel : noraini.mn@fpm.upsi.edu.my
}

Received : 27 September 2018; Accepted : 14 November 2018; Published : 29 Disember 2018

\begin{abstract}
Abstrak
Kajian ini bertujuan untuk membangunkan dan menguji kesan penggunaan koswer Nutri-Score dengan ejen pedagogi beranimasi bagi topik Nutrisi dalam Biologi Tingkatan Empat. Reka bentuk eksperimen kuasi digunakan. Persampelan kelompok tiga tahap dilaksanakan untuk memilih 181 responden dari masing-masing dua sekolah menengah di Kedah dan Pulau Pinang. Kumpulan rawatan mempelajari Nutrisi melalui Nutri-Score. Kumpulan kawalan mempelajari Nutrisi secara lazim. Pembolehubah-pembolehubah bersandar ialah kemahiran berfikir aras tinggi, kemahiran mengelaskan, kemahiran membandingbeza dan kemahiran menyelesaikan masalah mengikut Taksonomi Baru Model Marzano. Dapatan dianalisis dengan menggunakan ujian MANCOVA. Skor ujian pra dijadikan kovariat. Didapati penggunaan Nutri-Score telah meningkatkan kemahiran berfikir aras tinggi, kemahiran mengelaskan dan kemahiran membandingbeza secara signifikan. Justeru, reka bentuk dan pembangunan Nutri-Score boleh dijadikan panduan berguna untuk mereka bentuk dan membangunkan koswer pembelajaran bagi merangsang kemahiran berfikir aras tinggi.
\end{abstract}

Kata kunci Kemahiran Berfikir Aras Tinggi, Kemahiran Mengelaskan, Kemahiran Membanding Beza, Kemahiran Menyelesaikan Masalah, Multimedia Interaktif, Ejen Pedagogi.

\begin{abstract}
This study aims to develop and test the effect of using a courseware named Nutri-Score with an animated pedagogical agent on the topic of Nutrition in Form Four Biology. Quasi experimental design was used. A threestage cluster sampling was conducted to select 181 respondents from two secondary schools in Kedah and Penang respectively. The treatment group studied Nutrition through Nutri-Score. The control group studied Nutrition traditionally. The dependent variables were higher order thinking skills, classifying skills, comparing and contrasting skills and problem solving skills according to the Marzano Model. The findings were analyzed using
\end{abstract}


MANCOVA test. Pre-test scores were used as the covariate. Results showed that Nutri-Score has increased the higher order thinking skills, classifying skills and comparing and contrasting skills significantly. Hence, the design and development of Nutri-Score can serve as a useful guidance for designing and developing an interactive multimedia courseware in order to enhance higher order thinking skills.

Keywords $\quad$ Higher Order Thinking Skills, Classifying Skills, Comparing And Contrasting Skills, Problem Solving Skills, Interactive Multimedia, Pedagogical Agent.

\section{PENGENALAN}

Biologi merupakan satu subjek sains elektif yang diajar di peringkat atas sekolahsekolah menengah di Malaysia. Kurikulum Biologi Tingkatan Empat dibahagikan kepada empat tema iaitu Pengenalan kepada Biologi, Menyiasat Sel sebagai Unit Asas Kehidupan, Menyiasat Fisiologi Hidupan dan Menyiasat Perhubungan Hidupan dengan Persekitaran (Kementerian Pelajaran Malaysia, 2012). Nutrisi adalah topik keenam dan ia terkandung dalam tema Menyiasat Fisiologi Hidupan. Tema tersebut menunjukkan bahawa Nutrisi mengandungi proses-proses fisiologi yang abstrak dan mikroskopik yang tidak dapat dilihat dengan mata kasar.

Salah satu objektif yang perlu dicapai dalam pengajaran Biologi peringkat sekolah menengah adalah untuk meningkatkan kemahiran berfikir aras tinggi pelajar melalui kemahiran berfikir kritis dan kreatif. Kemahiran berfikir kritis termasuklah mencirikan, membandingbeza, mengumpul dan mengelaskan, membuat urutan, menyusun mengikut keutamaan, menganalisis, mengesan mengikut kecondongan, menilai dan membuat kesimpulan. Dalam topik Nutrisi, kemahiran berfikir kritis memberi tumpuan kepada kemahiran mengelaskan untuk pengajaran subtopik Memahami Jenis-jenis Nutrisi dan kemahiran membandingbeza untuk pengajaran subtopik Menganalisis Pencernaan Makanan. Oleh itu, bahan bantu mengajar untuk topik Nutrisi yang harus disediakan kepada atau oleh para guru mestilah yang dapat membantu meningkatkan kemahiran berfikir aras tinggi pelajar seperti kemahiran mengelaskan dan kemahiran membandingbeza.

Menurut Raja, Goodson dan Rohani (1998), strategi pengajaran untuk membangunkan kemahiran berfikir aras tinggi haruslah yang berpusatkan pelajar seperti aktiviti dalam kumpulan, perbincangan pelajar, bimbingan rakan sebaya, pembelajaran koperatif dan pembelajaran berbantukan komputer. Dalam spesifikasi kurikulum Biologi Tingkatan Empat, beberapa contoh strategi pengajaran untuk meningkatkan kemahiran berfikir aras tinggi dalam Nutrisi disyorkan kepada guru oleh Kementerian Pelajaran Malaysia. Contohnya, penggunaan animasi berkomputer untuk mengajar subtopik Penyerapan Dan Asimilasi Makanan Tercerna. Satu lagi strategi adalah melalui penerapan pembelajaran koperatif dalam kumpulan kecil pelajar untuk membincangkan subtopik-subtopik Pemakanan Seimbang, Malnutrisi, Menilai Tabiat Pemakanan dan Menyedari Kepentingan Sistem Pencernaan Yang Sihat. Justeru, pengkaji mengaplikasikan penggunaan animasi berkomputer dengan penambahan 
KESAN EJEN PEDAGOGI DAN RANGSANGAN MULTIMEDIA DALAM KOSWER NUTRI-SCORE TERHADAP KEMAHIRAN BERFIKIR ARAS TINGGI

strategi pembelajaran kontekstual dalam pembangunan koswer pembelajaran kepada kumpulan rawatan. Bagi kumpulan kawalan, strategi pembelajaran koperatif diterapkan memandangkan strategi ini sesuai untuk pembelajaran secara lazim (Siti Zubaidah, 2010).

\section{LATAR BELAKANG KAJIAN}

Masalah yang sering dihadapi oleh pelajar-pelajar Biologi adalah lemah dalam menguasai konsep-konsep asas Biologi. Antara topik Biologi yang mengandungi konsep Sains yang sukar untuk pelajar kuasai ialah Nutrisi. Masalah ini terbukti melalui dapatan kajian oleh Norsaliza (2018) terhadap 196 pelajar Biologi tingkatan empat yang mengakui sembilan daripada sepuluh subtopik dalam Nutrisi sebagai sukar manakala satu subtopik sebagai sangat sukar. Kelemahan untuk menguasai konsep Sains turut didedahkan oleh Lembaga Peperiksaan Malaysia (2010, 2013 \& 2014) mengenai calon-calon dari kumpulan prestasi rendah dalam peperiksaan Sijil Pelajaran Malaysia (Sijil Pelajaran Malaysia). Sekiranya masalah ini tidak dapat diatasi, peningkatan bilangan item kognitif aras tinggi dalam kertas Biologi Sijil Pelajaran Malaysia akan meruncingkan lagi keadaan. Walhal pemahaman yang mendalam terhadap konsepkonsep merupakan prasyarat untuk meningkatkan kemahiran berfikir aras tinggi dalam kalangan pelajar (Thomas \& Thorne, 2009).

Lembaga Peperiksaan Malaysia (2013 \& 2014) telah melaporkan bahawa calon-calon peperiksaan Sijil Pelajaran Malaysia dari kumpulan prestasi pertengahan gagal memberikan respons yang baik kepada item-item membandingbeza. Didapati juga item-item aras tinggi yang ditaksir dalam TIMSS dan PISA yang gagal dijawab dengan baik oleh pelajar-pelajar Malaysia adalah yang menguji kemahiran menyelesaikan masalah (Dossey, O'Sullivan \& Gonzales, 2006). Maka pengkaji menjalankan kajian ini berkenaan kemahiran berfikir aras tinggi dengan memberi tumpuan kepada kemahiran membandingbeza dan kemahiran menyelesaikan masalah. Di samping itu, pengkaji juga memilih kemahiran mengelaskan sebagai satu lagi pemboleh ubah bersandar. Kemahiran mengelaskan dan kemahiran membandingbeza adalah antara kemahiran berfikir aras tinggi yang terkandung dalam aras ketiga Taksonomi Baru Model Marzano, iaitu tahap analisis. Kemahiran menyelesaikan masalah terkandung dalam aras keempat iaitu penggunaan pengetahuan.

Di samping itu, guru-guru di Malaysia menghadapi cabaran untuk melaksanakan pengajaran berasaskan kemahiran berfikir aras tinggi walaupun dasar itu telah dimulakan sejak tahun 2013. Selain perlu mempunyai pengetahuan yang mencukupi dan sikap yang sesuai, mereka juga perlu mahir dalam teknik pedagogi tertentu supaya mampu meningkatkan kemahiran berfikir aras tinggi dalam kalangan pelajar (Barak \& Shakhman, 2008; Rajendran, 2010). Kursus-kursus dalaman dan pendedahan guru-guru kepada teknik menyoal didapati tidak mencukupi. Beban tugas dan kekangan masa, menghalang guru-guru daripada meneroka teknik pedagogi yang sesuai apalagi untuk menyediakan sendiri bahan bantu mengajar. Sebenarnya adalah lebih mudah jika guru-guru dapat menggunakan modul dan bahan yang dibekalkan sebagai bahan bantu mengajar berasaskan kemahiran berfikir aras tinggi kerana guruguru kini dibebani dengan banyak tanggungjawab harian (Rajendran, 2010). Justeru, 
bahan bantu mengajar seperti koswer multimedia yang disepadukan dengan strategi pengajaran kemahiran berfikir aras tinggi akan dapat meringankan tugas guru-guru.

Dimaklumi bahawa Kementerian Pelajaran Malaysia telah membekalkan koswer multimedia untuk subjek-subjek Matematik, Sains, Fizik, Kimia dan Biologi ke sekolah-sekolah menengah. Malangnya, MDEC (2008) melaporkan bahawa peratusan penggunaan koswer multimedia oleh guru-guru adalah sangat rendah iaitu kurang daripada 10\%. Para guru mendakwa bahawa koswer-koswer multimedia tersebut tidak membantu pelajar-pelajar untuk memahami konsep-konsep, pelajar tidak boleh mengakses koswer-koswer tersebut sendiri, kandungannya kurang relevan dengan pengalaman sebenar pelajar-pelajar, tidak mengikuti langkah-langkah strategi pengajaran yang betul dan sering menjejaskan operasi komputer. Pelajar-pelajar mengkritik koswer-koswer tersebut sebagai membosankan, mengurangkan interaksi dua hala dengan guru, grafik tidak menarik, contoh-contoh tidak jelas, tidak membantu mereka dalam pemahaman, tidak memberi mereka peluang untuk akses sendiri dan guru mereka jarang menggunakan koswer-koswer tersebut kerana mereka perlu mengeiar masa untuk bergerak ke kelas lain.

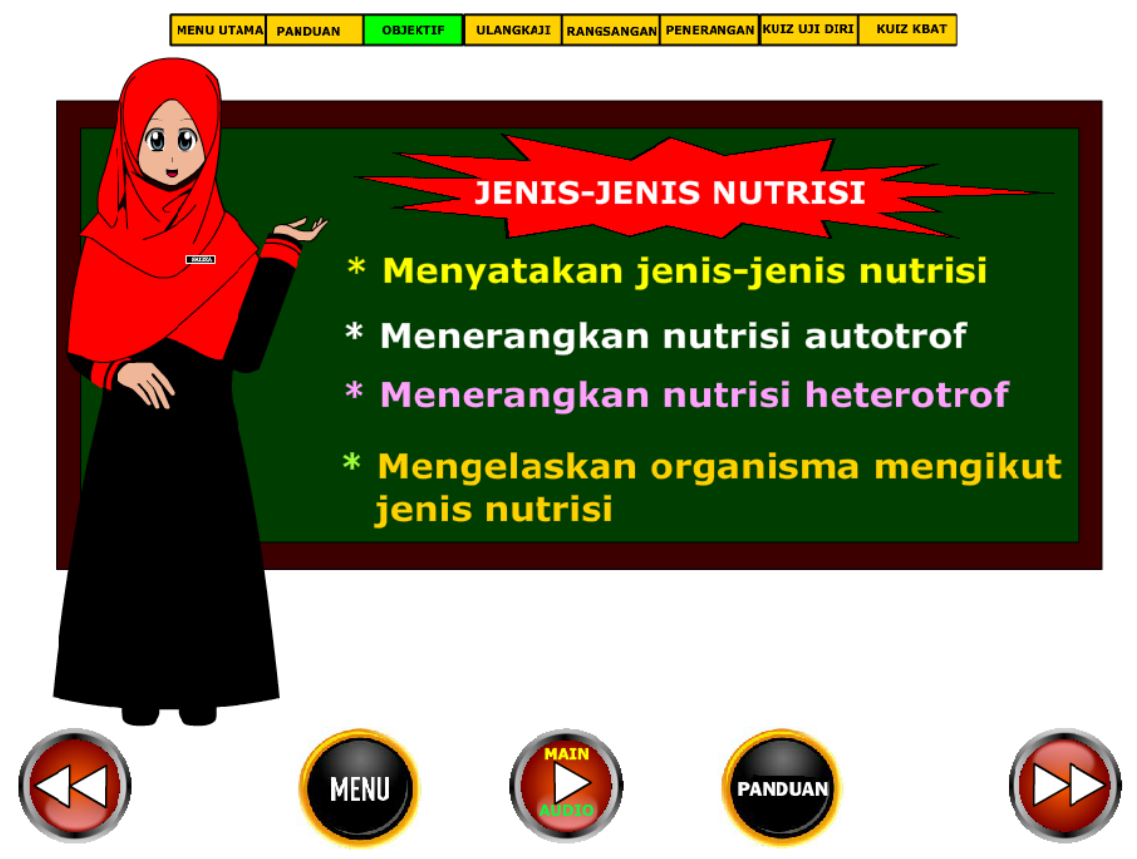

Rajah 1 Ejen pedagogi sedang menerangkan objektif bagi subtopik Jenis-jenis Nutrisi 
KESAN EJEN PEDAGOGI DAN RANGSANGAN MULTIMEDIA DALAM KOSWER NUTRI-SCORE TERHADAP KEMAHIRAN BERFIKIR ARAS TINGGI

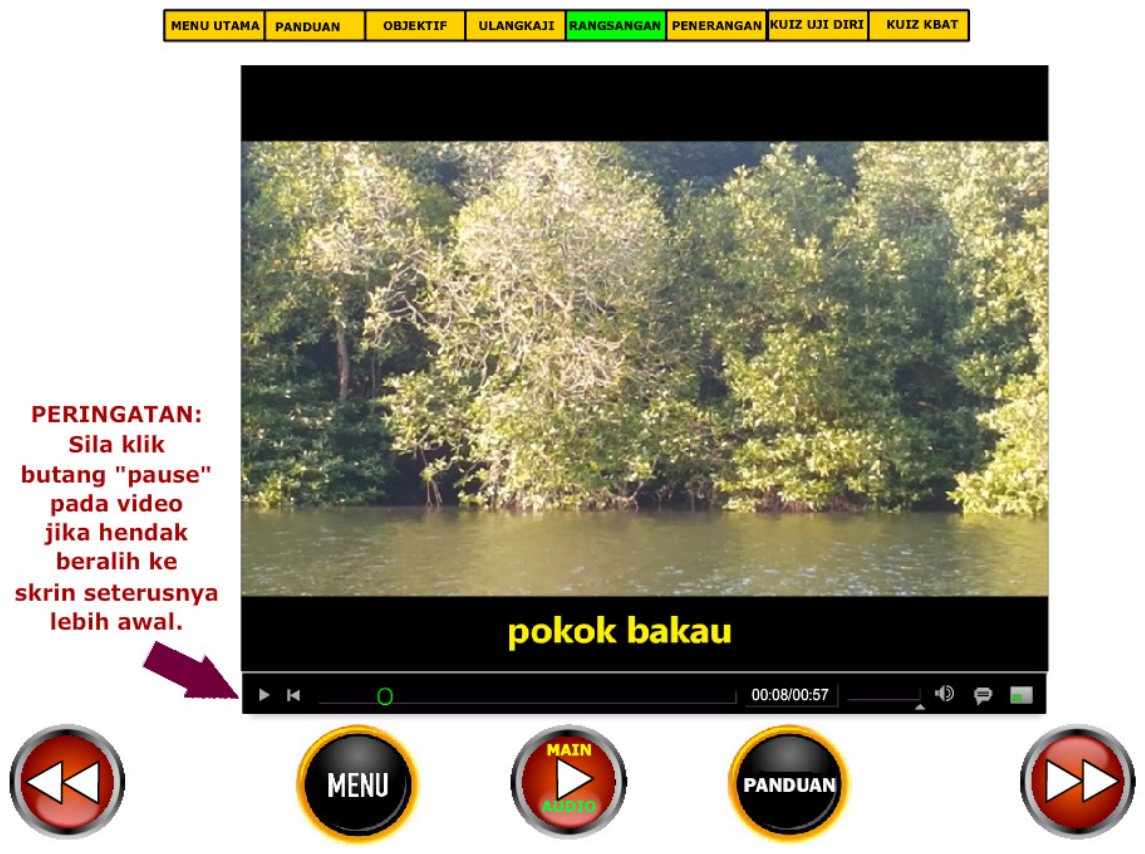

Rajah 2 Video interaktif menayangkan suasana ekosistem hutan bakau

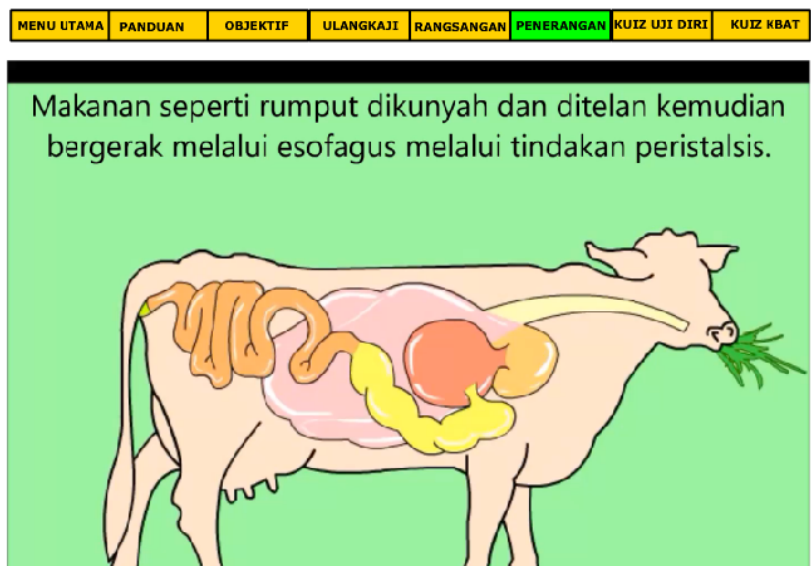

Rajah 3 Animasi interaktif menayangkan proses pencernaan makanan pada ruminan seperti lembu 
Pengkaji mengambil berat mengenai semua komen dari guru-guru dan pelajar-pelajar untuk meminimumkan kelemahan dalam Nutri-Score. Pengkaji menggabungkan Teori Kognitif Pembelajaran Multimedia (CTML), Teori Kognitif Pembelajaran Multimedia dengan Ejen Pedagogi Beranimasi (CTMLAPA) dan Teori Beban Kognitif untuk mereka bentuk dan membangunkan Nutri-Score. Ejen pedagogi beranimasi dengan watak kartun bernama Cikgu Saliza telah ditambahkan mengikut CTMLAPA. Ejen pedagogi tersebut memainkan empat peranan utama iaitu (i) seorang pakar yang memberikan maklumat, (ii) seorang mentor yang memberi nasihat, (iii) seorang motivator dan (iv) seorang rakan yang memberikan bantuan (Kim \& Baylor, 2008). Kandungan dalam Nutri-Score dipersembahkan langkah demi langkah mengikut sembilan langkah dalam Adegan Pengajaran oleh Gagne. Strategi pengajaran yang diaplikasikan adalah berdasarkan strategi pembelajaran kontekstual yang menyokong Teori Konstruktivisme. Rajah 4 menunjukkan carta alir proses reka bentuk dan pembangunan Nutri-Score.

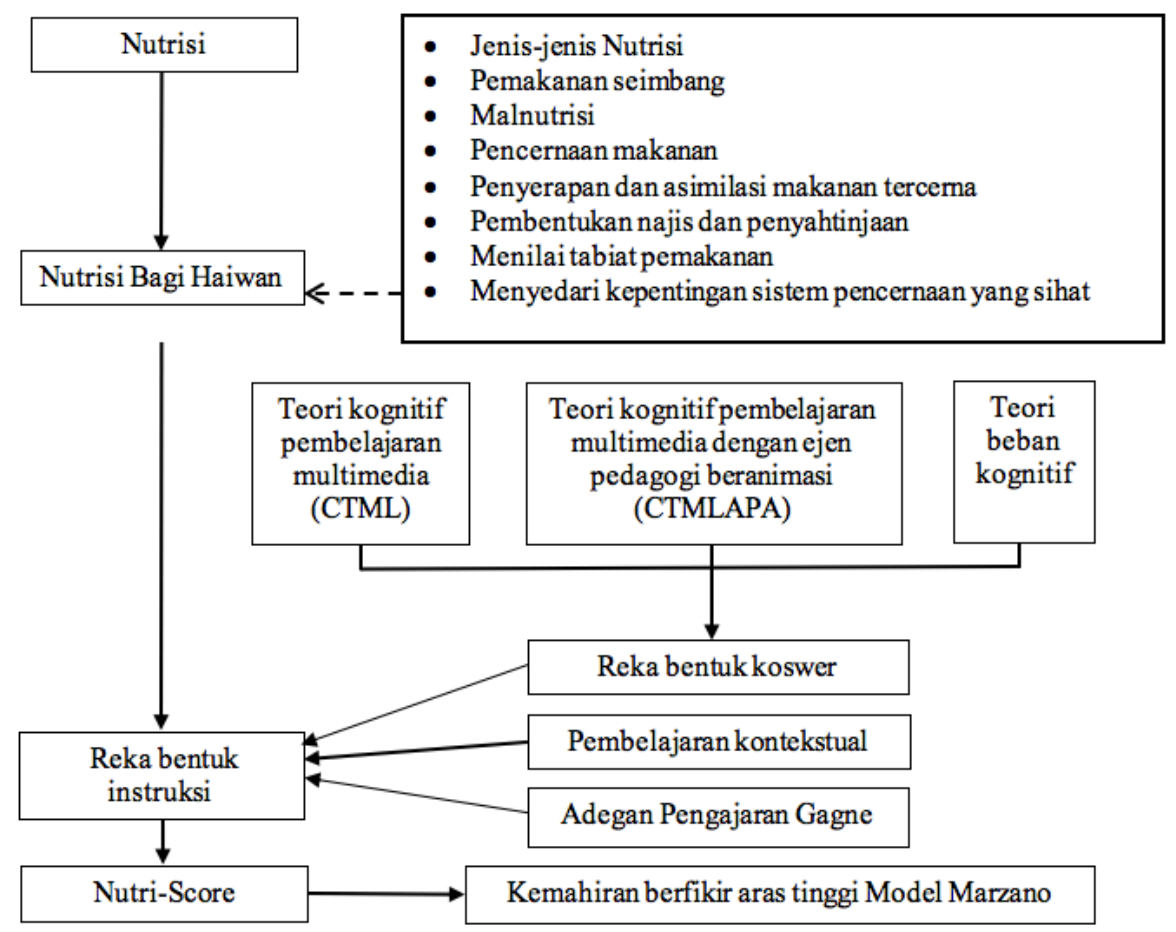

Rajah 4 Carta alir proses reka bentuk dan pembangunan Nutri-Score

\section{PERSOALAN KAJIAN}

Terdapat empat persoalan kajian dalam kajian ini iaitu:

(a) Adakah terdapat perbezaan yang signifikan dalam kemahiran berfikir aras tinggi antara kumpulan kawalan dan kumpulan rawatan? 
KESAN EJEN PEDAGOGI DAN RANGSANGAN MULTIMEDIA DALAM KOSWER NUTRI-SCORE TERHADAP KEMAHIRAN BERFIKIR ARAS TINGGI

(b) Adakah terdapat perbezaan yang signifikan dalam kemahiran mengelaskan antara kumpulan kawalan dan kumpulan rawatan?

(c) Adakah terdapat perbezaan yang signifikan dalam kemahiran membandingbeza antara kumpulan kawalan dan kumpulan rawatan?

(d) Adakah terdapat perbezaan yang signifikan dalam kemahiran menyelesaikan masalah antara kumpulan kawalan dan kumpulan rawatan?

\section{METODOLOGI}

Kajian ini menggunakan reka bentuk eksperimen kuasi dengan pendekatan kuantitatif untuk melihat kesan-akibat. Jenis reka bentuk eksperimen kuasi yang digunakan adalah reka bentuk ujian pra-pasca kumpulan tidak seimbang. Reka bentuk eksperimen kuasi digunakan dalam kajian ini kerana persampelan rawak tidak dapat dilakukan (Chua, 2006, White \& Sabarwal, 2014). Beberapa langkah untuk mengurangkan bias pemilihan dilaksanakan oleh pengkaji. Pengkaji memilih strategi pembelajaran koperatif yang merupakan satu contoh pembelajaran lazim untuk kumpulan kawalan. Kumpulan rawatan pula belajar melalui Nutri-Score. Ujian pra ditadbir sebelum rawatan manakala ujian pasca ditadbir selepas rawatan kepada kedua-dua kumpulan. Kecekapan rawatan $\left(\mathrm{X}_{1}\right.$ dan $\left.\mathrm{X}_{2}\right)$ dari segi kemahiran berfikir aras tinggi ditentukan dengan mengkaji perbezaan di antara skor min ujian pra dan ujian pasca kedua-dua kumpulan. Jadual 1 menggambarkan reka bentuk eksperimen kuasi yang dilaksanakan dalam kajian ini.

Jadual 1 Reka bentuk kajian

\begin{tabular}{lllll}
\hline Kumpulan & Intervensi & \multicolumn{3}{c}{ Ilustrasi reka bentuk } \\
\hline Rawatan & Nutri-Score & $\mathrm{O}_{1} \longrightarrow \mathrm{X}_{1} \longrightarrow \mathrm{O}_{2}$ \\
\hline Kawalan & Pembelajaran lazim & $\mathrm{O}_{1} \longrightarrow \mathrm{X}_{2}$ & $\longrightarrow \mathrm{O}_{2}$ \\
\hline
\end{tabular}

Petunjuk:

$\mathrm{X}_{1}=$ Pendedahan kepada Nutri-Score

$\mathrm{X}_{2}=$ Pendedahan kepada pembelajaran lazim

$\mathrm{O}_{1}=$ Proses penilaian pertama iaitu ujian pra

$\mathrm{O}_{2}=$ Proses penilaian kedua iaitu ujian pasca

$\longrightarrow=$ Urutan proses

Seramai 181 responden dari 2 buah sekolah menengah di Kedah dan 2 buah sekolah menengah di Pulau Pinang telah mengambil bahagian dalam kajian ini. Mereka dibahagikan kepada kumpulan rawatan dan kumpulan kawalan. Jadual 3 menunjukkan jumlah responden bagi setiap kumpulan mengikut mod pembelajaran yang digunakan. Setiap sekolah terpilih mengandungi satu kumpulan kawalan dan satu kumpulan rawatan. Sebelum responden menyertai sesi pembelajaran Nutrisi, mereka menjawab Ujian Kemasukan yang mengandungi 40 item aneka pilihan bagi lima topik sebelum topik Nutrisi. Tujuan Ujian Kemasukan ini adalah untuk mengetahui tahap pengetahuan 
sedia ada responden dalam Biologi kerana sebahagian besar konsep dalam lima topik terdahulu itu akan digunakan untuk memahami topik Nutrisi. Jadual 3 menunjukkan taburan responden mengikut negeri dan sekolah untuk kedua-dua kumpulan rawatan dan kawalan.

Jadual 3 Taburan responden mengikut kumpulan

\begin{tabular}{|c|c|c|c|c|}
\hline \multirow{2}{*}{ Negeri } & \multirow{2}{*}{ Sekolah } & \multicolumn{2}{|c|}{ Kumpulan } & \multirow{2}{*}{ Jumlah $(\mathrm{N})$} \\
\hline & & Kawalan (N) & Rawatan (N) & \\
\hline \multirow{2}{*}{ Kedah } & A & 30 & 23 & \multirow{2}{*}{110} \\
\hline & B & 29 & 28 & \\
\hline \multirow{3}{*}{ Pulau Pinang } & $\mathrm{C}$ & 18 & 21 & \multirow{2}{*}{71} \\
\hline & $\mathrm{D}$ & 14 & 18 & \\
\hline & Jumlah & 91 & 90 & 181 \\
\hline
\end{tabular}

Soalan ujian pra dan ujian pasca adalah berbeza dari segi kandungan tetapi serupa dari segi aras kognitif. Kedua-dua ujian pra dan ujian pasca terdiri daripada item jawapan pendek dan soalan-soalan esei. Item jawapan pendek menguji kemahiran mengelaskan manakala soalan-soalan esei menguji kemahiran membandingbeza. Semua item dalam ujian pra dan ujian pasca dibina dengan menggunakan Rubrics for Specific Tasks or Situations (Marzano, Pickering \& McTighe, 2005) dan diselaraskan dengan aras soalan peperiksaan Sijil Pelajaran Malaysia. Perbezaan dalam ujian pasca ialah tambahan lima gambarajah organisma untuk dikelaskan dalam item jawapan pendek. Bagi soalan esei, perbandingan antara sistem pencernaan manusia dan arnab diubah kepada perbandingan antara sistem pencernaan manusia dan lembu. Tujuan mengubahsuai item dalam ujian pasca adalah untuk menghalang responden daripada memberikan jawapan yang mereka hafal dari ujian pra.

\section{KEPUTUSAN}

Ujian Levene dalam ujian ANOVA sehala dilaksanakan terhadap skor Ujian Kemasukan untuk menguji sama ada responden kedua-dua kumpulan adalah setara dari segi pengetahuan sedia ada sebelum mempelajari topik Nutrisi. Hasil analisis yang ditunjukkan dalam Jadual 4 menunjukkan bahawa nilai signifikan untuk ujian Levene melebihi .05. Oleh itu, tidak terdapat perbezaan yang signifikan dalam pengetahuan sedia ada responden dari kumpulan rawatan dan kumpulan kawalan $(F(1,179)=0.107$, $p=.744)$. Ini mengesahkan bahawa responden dalam kedua-dua kumpulan adalah homogen dari segi pengetahuan sedia ada mereka. 
KESAN EJEN PEDAGOGI DAN RANGSANGAN MULTIMEDIA DALAM KOSWER NUTRI-SCORE TERHADAP KEMAHIRAN BERFIKIR ARAS TINGGI

Jadual 4 Analisis ujian Levene dalam Ujian ANOVA sehala bagi skor Ujian Kemasukan merentasi kumpulan

\begin{tabular}{llccc}
\hline Pembolehubah bersandar & Statistik Levene, $F$ & $d f 1$ & $d f 2$ & $p$ \\
\hline Ujian Kemasukan & 0.107 & 1 & 179 & .744 \\
\hline
\end{tabular}

Jadual 5 pula menunjukkan statistik deskriptif untuk empat pembolehubah bersandar daripada kumpulan rawatan dan kumpulan kawalan. Empat pembolehubah bersandar ialah kemahiran berfikir aras tinggi dan tiga komponennya iaitu kemahiran mengelaskan, kemahiran membandingbeza dan kemahiran menyelesaikan masalah. Didapati bahawa min kemahiran berfikir aras tinggi kumpulan rawatan iaitu 36.46 adalah lebih tinggi daripada kemahiran berfikir aras tinggi kumpulan kawalan iaitu 26.21 sebanyak 10.25. Untuk kemahiran mengelaskan, min kumpulan rawatan iaitu 57.00 juga melebihi min kumpulan kawalan iaitu 42.69 sebanyak 14.31. Min kemahiran membandingbeza kumpulan rawatan iaitu 25.11 melebihi dengan ketaranya min kemahiran membandingbeza kumpulan kawalan iaitu 7.58 sebanyak 17.53. Begitu juga, min kemahiran menyelesaikan masalah kumpulan rawatan iaitu 25.17 melebihi min kemahiran menyelesaikan masalah kumpulan kawalan sebanyak 6.13.

Jadual 5 Statistik deskriptif antara responden kumpulan rawatan dan kawalan

\begin{tabular}{lcccccc}
\hline & \multicolumn{3}{c}{ Kumpulan rawatan } & \multicolumn{3}{c}{ Kumpulan kawalan } \\
\cline { 2 - 7 } Pembolehubah bersandar & Min & $\begin{array}{c}\text { Sisihan } \\
\text { piawai }\end{array}$ & Bil. & Min & $\begin{array}{c}\text { Sisihan } \\
\text { piawai }\end{array}$ & Bil. \\
\hline Kemahiran berfikir aras tinggi & 36.46 & 12.13 & 26.21 & 11.37 & \\
Kemahiran mengelaskan & 57.00 & 18.48 & 42.69 & 21.48 & \\
Kemahiran membandingbeza & 25.11 & 18.19 & 90 & 7.58 & 8.21 & 91 \\
Kemahiran menyelesaikan masalah & 25.17 & 19.04 & 30.49 & 17.11 & \\
\hline
\end{tabular}

Ujian Multivariate Analysis of Covariance (MANCOVA) digunakan untuk menganalisis data seterusnya dalam kajian ini dengan menggunakan ujian pra sebagai kovariat. Hasil daripada ujian Multivariate Pillai's Trace dalam Jadual 6 menunjukkan bahawa terdapat kesan yang signifikan oleh kumpulan $[F(4,175)=22.07, p<.05]$. Kesimpulannya, kumpulan merupakan faktor yang menyumbang kepada peningkatan kemahiran berfikir aras tinggi, kemahiran mengelaskan, kemahiran membandingbeza dan kemahiran menyelesaikan masalah oleh responden. Selanjutnya dilaksanakan ujian univariat Tests of Between-Subjects Effects, ujian Estimated Marginal Means dan ujian post hoc Bonferroni Adjusted Pairwise Comparison. 
Jadual 6 Keputusan ujian Multivariate Pillai's Trace

\begin{tabular}{lccccc}
\hline Pembolehubah tidak bersandar & Nilai & F & Hipotesis df & Ralat df & p \\
\hline Kumpulan & 0.34 & 22.07 & 4.00 & 175.00 & .00 \\
\hline
\end{tabular}

Jadual 7 menunjukkan keputusan ujian univariat Tests of Between-Subjects Effects. Keputusan ini menunjukkan bahawa terdapat kesan kumpulan yang signifikan kepada kemahiran berfikir aras tinggi $[F(1,178)=26.72, p<.05]$. Nilai $R^{2}$ menunjukkan bahawa pembolehubah tidak bersandar iaitu kumpulan menyumbang sebanyak $30.6 \%$ perubahan dalam kemahiran berfikir aras tinggi. Dapatan juga menunjukkan bahawa terdapat kesan kumpulan yang signifikan kepada kemahiran mengelaskan $[F(1,178)=18.83, p<.05]$. Nilai $R^{2}$ menunjukkan bahawa pemboleh ubah tidak bersandar iaitu kumpulan menyumbang sebanyak $14.0 \%$ perubahan kepada kemahiran mengelaskan. Di samping itu, terdapat kesan kumpulan yang ketara kepada kemahiran membandingbeza $[F(1,178)=60.96, p<.05]$. Nilai $R^{2}$ menunjukkan bahawa pembolehubah tidak bersandar iaitu kumpulan menyumbang 35.6\% perubahan kepada kemahiran membandingbeza. Akhirnya, terdapat kesan kumpulan yang ketara kepada kemahiran menyelesaikan masalah $[F(1,178)=9.22 p<.05]$. Nilai $R^{2}$ menunjukkan bahawa pemboleh ubah tidak bersandar iaitu kumpulan menyumbang $14.7 \%$ perubahan kepada kemahiran membandingbeza.

Jadual 7 Keputusan Tests of Between-Subjects Effects

\begin{tabular}{llcccccc}
\hline $\begin{array}{l}\text { Pembolehubah } \\
\text { bersandar }\end{array}$ & Sumber & $\begin{array}{c}\text { Kuasa dua } \\
\text { jenis III }\end{array}$ & df & $\begin{array}{c}\text { Min kuasa } \\
\text { dua }\end{array}$ & F & p & $\mathrm{R}^{2}$ \\
\hline $\begin{array}{l}\text { Kemahiran } \\
\text { berfikir aras } \\
\text { tinggi }\end{array}$ & Kumpulan & 3073.68 & 1 & 3073.68 & 26.72 & 0.00 & 0.306 \\
$\begin{array}{l}\text { Kemahiran } \\
\text { mengelaskan }\end{array}$ & Kalat & 20475.96 & 178 & 115.03 & & & \\
\cline { 2 - 8 } & Kumpulan & 7386.61 & 1 & 7386.61 & 18.83 & 0.00 & 0.140 \\
$\begin{array}{l}\text { Kemahiran } \\
\text { membandingbeza }\end{array}$ & Kumpulan & 10902.52 & 1 & 10902.52 & 60.96 & 0.00 & 0.356 \\
$\begin{array}{lllllll}\text { Kemahiran } \\
\text { menyelesaikan } \\
\text { masalah }\end{array}$ & Kumpulan & 2648.94 & 1 & 2648.94 & 9.22 & 0.00 & 0.147 \\
\cline { 2 - 8 } & Ralat & 51125.76 & 178 & 287.22 & & & \\
\cline { 2 - 8 }
\end{tabular}

Keputusan ujian Estimated Marginal Means (Jadual 8) menunjukkan min terubahsuai bagi kemahiran berfikir aras tinggi untuk kumpulan rawatan iaitu 35.52 adalah lebih tinggi daripada min terubahsuai untuk kumpulan kawalan iaitu 27.13 sebanyak 8.39. Keputusan ujian post hoc Bonferroni Adjusted Pairwise Comparison (Jadual 9) mengesahkan bahawa perbezaan tersebut adalah signifikan kerana $p<.05$. Maka, kemahiran berfikir aras tinggi untuk kumpulan rawatan adalah lebih baik berbanding dengan kumpulan kawalan. 
KESAN EJEN PEDAGOGI DAN RANGSANGAN MULTIMEDIA DALAM KOSWER NUTRI-SCORE TERHADAP KEMAHIRAN BERFIKIR ARAS TINGGI

Keputusan ujian Estimated Marginal Means (Jadual 8) menunjukkan min terubahsuai bagi kemahiran mengelaskan untuk kumpulan rawatan iaitu 56.35 adalah lebih tinggi daripada min terubahsuai bagi kumpulan kawalan iaitu 43.34 sebanyak 13.01. Keputusan ujian post hoc Bonferroni Adjusted Pairwise Comparison (Jadual 9) mengesahkan bahawa perbezaan tersebut adalah signifikan kerana $p<.05$. Maka, kemahiran mengelaskan untuk kumpulan rawatan adalah lebih baik berbanding dengan kumpulan kawalan.

Keputusan ujian Estimated Marginal Means (Jadual 8) menunjukkan min terubahsuai bagi kemahiran membandingbeza untuk kumpulan rawatan iaitu 24.24 adalah lebih tinggi daripada min terubahsuai untuk kumpulan kawalan iaitu 8.44 sebanyak 15.80. Keputusan ujian post hoc Bonferroni Adjusted Pairwise Comparison (Jadual 9) mengesahkan bahawa perbezaan tersebut adalah signifikan kerana $p<.05$. Maka, kemahiran membandingbeza untuk kumpulan rawatan adalah lebih baik berbanding dengan kumpulan kawalan.

Keputusan ujian Estimated Marginal Means (Jadual 8) menunjukkan min terubahsuai bagi kemahiran menyelesaikan masalah untuk kumpulan rawatan iaitu 23.93 adalah kurang daripada min terubahsuai untuk kumpulan kawalan iaitu 31.72 sebanyak 7.79. Keputusan ujian post hoc Bonferroni Adjusted Pairwise Comparison (Jadual 9) mengesahkan bahawa perbezaan tersebut adalah signifikan kerana $p<.05$. Maka, kemahiran menyelesaikan masalah untuk kumpulan kawalan adalah lebih baik berbanding dengan kumpulan rawatan.

Jadual 8 Keputusan ujian Estimated Marginal Means

\begin{tabular}{lccc}
\hline Pembolehubah bersandar & Kumpulan & Min terubahsuai & Ralat piawai \\
\hline \multirow{2}{*}{ Kemahiran berfikir aras tinggi } & Rawatan & 35.52 & 1.14 \\
& Kawalan & 27.13 & 1.14 \\
\cline { 2 - 4 } Kemahiran mengelaskan & Rawatan & 56.35 & 2.11 \\
& Kawalan & 43.34 & 2.10 \\
\cline { 2 - 4 } Kemahiran membandingbeza & Rawatan & 24.24 & 1.42 \\
\multirow{2}{*}{ Kemahiran menyelesaikan masalah } & Kawalan & 8.44 & 1.42 \\
\cline { 2 - 4 } & Rawatan & 23.93 & 1.80 \\
\cline { 2 - 4 } & Kawalan & 31.72 & 1.79 \\
\hline
\end{tabular}

Jadual 9 Keputusan Ujian Bonferroni Adjusted Pairwise Comparison

\begin{tabular}{lccccc}
\hline $\begin{array}{l}\text { Pembolehubah } \\
\text { bersandar }\end{array}$ & $\begin{array}{c}\text { Kumpulan } \\
(\mathrm{I})\end{array}$ & $\begin{array}{c}\text { Kumpulan } \\
(\mathrm{II})\end{array}$ & $\begin{array}{c}\text { Perbezaan min } \\
(\mathrm{I}-\mathrm{II})\end{array}$ & Ralat piawai & $\mathrm{p}$ \\
\hline $\begin{array}{l}\text { Kemahiran berfikir } \\
\text { aras tinggi }\end{array}$ & Rawatan & Rawatan & 8.39 & 1.62 & .00 \\
& Kawalan & Kawalan & -8.39 & 1.62 & .00 \\
\cline { 2 - 6 } $\begin{array}{l}\text { Kemahiran } \\
\text { mengelaskan }\end{array}$ & Rawatan & Rawatan & 13.01 & 3.00 & .00 \\
& Kawalan & Kawalan & -13.01 & 3.00 & .00 \\
\hline
\end{tabular}




\begin{tabular}{lccccc}
\cline { 2 - 5 } $\begin{array}{l}\text { Kemahiran } \\
\text { membanding beza }\end{array}$ & Rawatan & Rawatan & 15.80 & 2.02 & .00 \\
$\begin{array}{l}\text { Kemahiran } \\
\text { menyelesaikan }\end{array}$ & Kawalan & Kawalan & -15.80 & 2.02 & .00 \\
\cline { 2 - 6 } masalah & Kawalan & Rawatan & -7.79 & 2.57 & .03 \\
\hline
\end{tabular}

\section{PERBINCANGAN}

Nutri-Score merupakan sebuah koswer pembelajaran yang mengintegrasikan teknologi multimedia dan ejen pedagogi di dalamnya untuk menyampaikan pengajaran topik Nutrisi. Nutri-Score juga bersifat interaktif. Teknologi yang terkandung dalam Nutri-Score berperanan meningkatkan kemahiran berfikir aras tinggi responden dari aspek kemahiran mengelaskan dan kemahiran membandingbeza kecuali kemahiran menyelesaikan masalah. Dapatan kajian oleh Wenglinsky (1998) didapati selari dengan dapatan ini yang mana kemahiran berfikir aras tinggi responden meningkat setelah diajar dengan menggunakan teknologi multimedia. Kajian oleh Satyaprakasha dan Sunitha (2014) yang menggunakan koswer multimedia interaktif untuk mengajar Biologi kepada pelajar-pelajar kelas VIII memperkuatkan dapatan ini kerana terdapat peningkatan dalam skor pencapaian responden dalam kemahiran mengaplikasi.

Teknologi multimedia yang terkandung dalam Nutri-Score adalah audio suara ejen pedagogi, teks penerangan ringkas dan kata-kata kunci, imej-imej dari gambarfoto-gambarfoto yang diambil sendiri oleh pengkaji, video-video tingkahlaku manusia dan haiwan ketika sedang makan yang dirakamkan oleh pengkaji, video animasi pergerakan bahan-bahan dalam sistem pencernaan manusia, arnab dan lembu serta ejen pedagogi beranimasi. Di samping itu, pengkaji turut merakamkan video yang menunjukkan situasi sebenar ekosistem bakau dan ekosistem sawah padi yang ditayangkan sebelum mengajar kemahiran mengelaskan organisma. Video-video ini secara tidak langsung menggalakkan pembelajaran kontekstual kerana mendedahkan pelajar kepada pengalaman hidup di dunia sebenar. Ejen pedagogi beranimasi yang ditayangkan dalam beberapa slaid pembelajaran telah berjaya menarik minat responden dan mendorong mereka untuk menyempurnakan pembelajaran Nutrisi melalui NutriScore.

\section{KESIMPULAN}

Keputusan analisis data menunjukkan bahawa pencapaian responden dari kumpulan rawatan secara signifikan melebihi pencapaian responden dari kumpulan kawalan dari aspek kemahiran berfikir aras tinggi dan dua komponen kemahiran berfikir aras tinggi iaitu kemahiran mengelaskan serta kemahiran membandingbeza. Keputusan ini menunjukkan bahawa koswer multimedia yang disepadukan dengan pelbagai teknologi multimedia, model-model dan teori-teori yang sesuai seperti dalam Nutri-Score secara amnya berupaya untuk meningkatkan kemahiran berfikir aras tinggi. Pengkaji menyarankan agar lebih banyak koswer pembelajaran Biologi dan subjek-subjek Sains lain dibangunkan dengan mengambil panduan kepada ciri-ciri pembangunan Nutri- 
KESAN EJEN PEDAGOGI DAN RANGSANGAN MULTIMEDIA DALAM KOSWER NUTRI-SCORE TERHADAP KEMAHIRAN BERFIKIR ARAS TINGGI

Score. Tujuannya ialah untuk membantu para guru meningkatkan kemahiran berfikir aras tinggi para pelajar mereka dalam Biologi dan subjek-subjek Sains lain.

\section{RUJUKAN}

Barak, M. \& Shakhman, L. (2008). Fostering higher-order thinking in science class: Teachers' reflections. Teachers and Teaching: Theory and Practice, 14(3), 191208. doi: 10.1080/13540600802006079

Chua, Y. P. (2006). Kaedah dan statistik pengkajian: Kaedah pengkajian (Buku 1). Shah Alam: McGraw-Hill Education (Malaysia) Sdn. Bhd.

Kementerian Pelajaran Malaysia (2012). Spesifikasi kurikulum Biologi tingkatan empat. Putrajaya: Bahagian Perkembangan Kurikulum, Kementerian Pelajaran Malaysia.

Kim, C., \& Baylor,A. L. (2008). A virtual change agent: Motivating pre-service teachers in their future classrooms. Educational Technology and Society, 11(2), 309-321. Diperolehi daripada https://www.researchgate.net/publication/220374597_A_ Virtual_Change_Agent_Motivating_Preservice_Teachers_to_Integrate_ Technology_in_Their_Future_Classrooms

King, F.J., Goodson, L., \& Rohani, F. (2009). Higher order thinking skills. Center for Advancement of Learning and Assessment. Diperolehi daripada http://www.cala. fsu.edu/files/higher_order_thinking_skills.pdf

Lembaga Peperiksaan Malaysia (2010). Kupasan mutu jawapan SPM 2010 Biologi 2 4551/2. Putrajaya.

Lembaga Peperiksaan Malaysia (2013). Kupasan mutu jawapan SPM 2013 Biologi 2 4551/2. Putrajaya.

Lembaga Peperiksaan Malaysia (2014). Kupasan mutu jawapan SPM 2014 Biologi 2 4551/2. Putrajaya.

Marzano, R. J., Pickering, D., \& McTighe, J. (2005). Assessing student outcomes: Performance assessment using the dimensions of learning model. Alexandria, Virginia: Association for Supervision and Curriculum Development (ASCD).

MDEC (2008). Penilaian koswer-koswer kursus Kementerian Pelajaran Malaysia. Diperolehi daripada http://www.mscmalaysia.my/sites/default/files/pdf/ publications references/ Penilaian_Koswer__Koswer_Kursus.pdf.

Norsaliza Sabu \& Noraini Mohamed Noh (2018). The need for creativity in teaching higher order thinking skills in Biology. International Journal of Academic Research in Business and Social Sciences, 8(1), 889-898. doi: 10.6007/IJARBSS/ v8-i1/3957.

Rajendran, N. S. (2010). Teaching and acquiring higher-order thinking skills: Theory and practise. Tanjong Malim: Sultan Idris Education University.

Satyaprakasha, C. V., \& Sunitha, B. (2014). Effectiveness of multimedia teaching on achievement of VIII standard students in Biologi. International Journal of Informative \& Futuristic Research, 1(8). Diperolehi daripada http://www.ijifr. com/pdfsave/27-04-201442320-04-2014302Dr\%20CVS\%20ACH\% 20a3a.pdf 
Siti Zubaidah (2010). Pembelajaran koperatif dan group investigation (sebagai salah satu teknik pembelajaran kolaboratif). Diperolehi daripada: https:// www. researchgate.net/publication/318040393

Thomas, A., \& Thorne. G. (2009). How to increase higher level thinking. The Centre for Development and Learning. Diperolehi daripada http://www.cdl.org/articles/ how-to-increase-high-order-thinking/

Wenglinsky, H. (1998). Does it compute? The relationship between educational technology and student achievement in Mathematics. Educational Testing Service Policy Information Center. Diperolehi daripada www.mff.org/pubs/ME161.pdf

White, H., \& Sabarwal, S. (2014). Quasi-experimental design and methods. Florence, Italy: United Nations Children's Fund (UNICEF). Diperolehi daripada https:// www.unicef-irc.org/publications/pdf/brief_8_quasi-experimental\%20design_eng. pdf 